\begin{abstract}
Iranica
Abstracta Iranica Revue bibliographique pour le domaine irano-aryen

Volume 32-33 | 2013

Comptes rendus des publications de 2009-2010
\end{abstract}

\title{
Philip C. Schmitz. The Owl on Phoenician Mortuary Practice
}

\section{Astrid Nunn}

\section{(2) OpenEdition}

1 Journals

\section{Édition électronique}

URL : http://journals.openedition.org/abstractairanica/40414

DOI : 10.4000/abstractairanica.40414

ISSN : 1961-960X

Éditeur :

CNRS (UMR 7528 Mondes iraniens et indiens), Éditions de l'IFRI

\section{Édition imprimée}

Date de publication : 1 décembre 2013

ISSN : 0240-8910

\section{Référence électronique}

Astrid Nunn, «Philip C. Schmitz. The Owl on Phoenician Mortuary Practice», Abstracta Iranica [En ligne], Volume 32-33 | 2013, document 116, mis en ligne le 01 juillet 2016, consulté le 27 septembre 2020. URL : http://journals.openedition.org/abstractairanica/40414; DOI : https://doi.org/10.4000/ abstractairanica. 40414

Ce document a été généré automatiquement le 27 septembre 2020.

Tous droits réservés 


\title{
Philip C. Schmitz. The Owl on Phoenician Mortuary Practice
}

\author{
Astrid Nunn
}

\section{RÉFÉRENCE}

Philip C. Schmitz. « The Owl on Phoenician Mortuary Practice ». JANER 9/1, 2009, p. 51-85.

1 Des os de hiboux, dont certains avaient été bouillis, on été retrouvés dans une tombe de l'âge du Fer dans la nécropole de Tyr. Cette trouvaille insolite incite l'A. à des considérations plus générales sur le symbolisme du hibou dans les rites funéraires antiques. Parmi les textes cités, certains sont achéménides (texte de Pyrgi, un autre sur une situle du Princeton Museum). Trois interprétations s'offrent à nous: le hibou symbolise soit une désolation personnelle et sociale d'un ou de plusieurs survivants, soit la vie de l'âme après la mort. Peut-être encore, ses os bouillis servaient de médecine au défunt, particulièrement s'il avait été aveugle.

\section{AUTEURS}

\section{ASTRID NUNN}

Université de Munich 